DOI: 10.26699/jnk.v1i1.ART.p041-046

This is an Open Access article under the CC BY-SA license (http://creativecommons.org/licenses/by-sa/4.0/)

\title{
PENGARUH PENYULUHAN TERHADAP SIKAP IBU MENANGANI FEBRIS \\ PASCA IMUNISASI DPT
}

\section{(The Effect of Health Education to the Mother's Attitude in Handling Febrille Post DPT Immunization)}

\author{
Lia Rahmawati*), Wahyu Wibisono**) \\ STIKes Patria Husada Blitar \\ e-mail: wahyu_kuromon@yahoo.com
}

\begin{abstract}
Introduction: DPT is an attempt to get immunity against the disease Diphtheria, Pertussis, Tetanus by entering the germs of diphtheria, pertussis, tetanus that have been weakened and turned off into the body so that the body can produce antibodies that will be used for the the body to fight the germs or the three of the disease (Markum, 2005). The aim of this study was to determine the effectiveness health promotion to the mother's attitudes post DPT immunization on the 3-5 months infants. Method: Research design was Pre-Experimental design using Pre - Post Test approach. Research sample was 19 mothers with infants aged 3-5 months at Pustu slorok District of Garum at June 25 ${ }^{\text {th }}$ until June $27^{\text {th }}, 2012$, its choosed with total sampling. Data collected by questionaire. Analysis using Wilcoxon Sign Rank Test, with $\leq 0.05$ significant level. Result: The results showed that there was an effect of health promotion to the mother's attitudes in handling in febrile post DPT, with $p$ value of 0.046. Discussion: Based on the results of the research,it was expected for the respondents to be more active in improving knowledge by emphasizing on information about febrile post DPT immunization either electronic nor mass media so respondents could improve the attitude in handling the febrile post DPT and minimize the occurrence of Kipi ( Genesis Infection Post Immunization ).
\end{abstract}

Keywords : attitudes , febrile post DPT immunization

\section{PENDAHULUAN}

Imunisasi DPT (Diphteri, Pertusis dan Tetanus) merupakan imunisasi yang digunakan untuk mencegah terjadinya penyakit difteri. Imunisasi DPT ini merupakan vaksin yang mengandung racun kuman difteri yang telah dihilangkan sifat racunnya akan tetapi masih dapat merangsang pembentukkan zat anti (toksoid). Frekuensi pemberian imunisasi DPT adalah tiga kali, dengan maksud pemberian pertama zat anti terbentuk masih sangat sedikit (tahap pengenalan)

terhadap vaksin dan mengaktifkan organorgan tubuh membuat zat anti, kedua dan ketiga terbentuk zat anti yang cukup (Alimul, 2008). Salah satu upaya agar anak-anak jangan sampai menderita suatu penyakit adalah dengan jalan memberikan imunisasi. Dengan imunisasi ini tubuh akan membuat zat anti dalam jumlah banyak, sehingga anak tersebut kebal terhadap penyakit. Jadi tujuan imunisasi DPT adalah membuat anak kebal terhadap penyakit Difteri, Pertusis, Tetanus (Markum, 2005). Secara alamiah sampai batas tertentu tubuh juga memiliki cara membuat kekebalan tubuh sendiri dengan masuknya kuman-kuman kedalam tubuh. Namun bila jumlah yang masuk cukup banyak dan ganas, bayi akan sakit. Dengan semakin berkembangnya teknologi dunia kedokteran, sakit berat masih bisaditanggulangi dengan obatobatan. Namun bagaimanapun juga pencegahan adalah jauh lebih baik dari pada pengobatan (Markum, 2005). Kirakira pada separuh penerima DPT akan terjadi kemerahan, bengkak dan nyeri 
pada lokasi injeksi dan demam. Efek samping pada DPT mempunyai efek ringan dan efek berat, efek ringan seperti pembengkakan dan nyeri pada tempat penyuntikan dan demam, sedangkan efek berat dapat menangis hebat kesakitan kurang lebih empat jam, kesadaran menurun, terjadi kejang, ensefalopati, dan shock (Alimul, 2008). Menurut Youssef et al, bahwa 95\% ibu khawatir bila anaknya demam. Alasan ibu karena demam pada anak dapat menyebabkan kejang (69\%), kerusakan otak (16\%), koma (14\%), gejala dari penyakit yang berat (11\%), bahkan demam bisa menyebabkan kematian. Kekhawatiran ibu tersebut terkadang sangat berlebihan dan juga tidak realistik, seperti selalu memanggil petugas kesehatan walaupun demamnya tidak tinggi (Youssef et al, 2002).

Ibu merupakan salah satu bagian yang dapat menunjang pencegahan demam pada anak. Dari segi usia, pendidikan, pekerjaan, pengalaman merawat anak akan memperhatikan bagaimana pencegahan demam. Begitu juga ketika anak mengalami demam, ibu harus mempunyai sikap yang tepat untuk menghadapinya. Sikap merupakan suatu pengetahuan yang disertai kesediaan kecenderungan bertindak. Sikap seorang ibu dalam menghadapi demam akan sangat mempengaruhi apakah demam akan menurun atau meningkat. Ibu yang mengetahui demam dan memiliki sikap yang baik dalam memberikan perawatan dapat mencegah dampak negatif demam yang tidak diatasi dengan benar (Harjaningrum, 2004). Dilihat dari peran ibu yang begitu besar dalan merawat serta memantau tumbuh kembang anak maka penyuluhan tantang imunisasi DPT serta dampaknya dirasa perlu dilakukan agar ibu tahu cara menangani demam yang terjadi pasca imunisasi secara tepat. Selain itu juga penyuluhan perlu dilakukan karena masih ada ibu yang khawatir berlebihan bila terjadi demam pasca imunisasi DPT. Menurut studi pendahuluan yang dilakukan tanggal 20 Mei 2013 di Wilayah kerja Pustu Slorok Kecamatan Garum pada bulan April jumlah ibu yang memiliki bayi usia 3-5 bulan sebanyak 27 ibu. Pada wilayah tersebut didapatkan laporan sekitar lebih dari $50 \%$ ibu masih khawatir dengan adanya efek samping demam pasca imunisasi DPT. Setelah diadakannya penyuluhan diharapkan ibu akan dapat memiliki sikap yang tepat dalam menangani dampak panas yang di timbulkan oleh imunisasi DPT. Berdasarkan latar belakang di atas maka peneliti tertarik untuk meneliti tentang Pengaruh Penyuluhan Imunisasi DPT Terhadap Sikap Ibu Dalam Menangani Febris Pada Bayi Usia 3-5 Bulan Pasca Imunisasi DPT Di Pustu Slorok Kecamatan Garum.

Rumusan masalahnya adalah adakah pengaruh penyuluhan imunisasi dpt terhadap sikap ibu dalam menangani febris pada bayi usia 3-5 bulan pasca imunisasi DPT di pustu slorok kecamatan garum.

Tujuan umumnya adalah mengetahui pengaruh penyuluhan terhadap sikap ibu menangani febris pasca imunisasi DPT pada bayi usia 3-5 bulan di Pustu Slorok Kecamatan Garum. Sedangkan tujuan khususnya adalah 1) Mengidentifikasi sikap ibu sebelum diberikan penyuluhan, 2) Mengidentifikasi sikap ibu setelah diberi penyuluhan, 3) Menganalisis pengaruh penyuluhan terhadap sikap ibu dalam menangani febris pada bayi usia 3-5 bulan pasca imunisasi DPT di Pustu Slorok Kecamatan Garum.

Manfaat penelitian ini dapat dijadikan sebagai dasar masukan atau informasi terutama bagi tenaga kesehatan dalam memberikan pelayanan imunisasi pada balita serta sebagai referensi bagi mahasiswa dalam pengkajian dan penelitian lebih lanjut tentang pengaruh penyuluhan imunisasi DPT terhadap sikap ibu dalam menangani febris pada bayi usia 3-5 bulan pasca imunisasi.

\section{BAHAN dan METODE}

Desain penelitian ini adalah PreExperiment Design dengan pendekatan Pre- Post Test Design dilakukan untuk mengetahui pengaruh penyuluhan terhadap sikap ibu menangani febris pasca imunisasi DPT pada bayi usia 3-5 bulan. Penelitian dilakukan di Pustu Slorok Kecamatan Garum, karena berdasarkan survey yang dilakukan peneliti bahwa ibu 
yang memiliki bayi usia 3-5 bulan masih memiliki tingkat kecemasan yang tinggi bila terjadi febris pasca imunisasi DPT.

Sampel dalam penelitian ini adalah 19 ibu yang memiliki bayi usia 3-5 bulan di Pustu Slorok Kecamatan Garum pada 25 - 27 Juni 2013, yang dipilih dengan teknik sampling jenuh atau total sampling.

Variabel bebasnya adalah penyuluhan tentang imunisasi DPT. Variabel tergantungnya adalah sikap ibu

\section{HASILPENELITIAN}

Tabel 1 Karakteristik responden

\begin{tabular}{|c|c|c|c|}
\hline No & Karakteristik & $\mathbf{f}$ & $\%$ \\
\hline \multirow[t]{5}{*}{1} & Umur : & & \\
\hline & $-15-20$ th & 3 & 15,8 \\
\hline & $-21-25$ th & 3 & 15,8 \\
\hline & $-26-30$ th & 8 & 42,1 \\
\hline & $->30$ th & 5 & 26,3 \\
\hline \multirow[t]{5}{*}{2} & Pendidikan: & & \\
\hline & $-\mathrm{SD}$ & 3 & 15,8 \\
\hline & - SLTP & 7 & 36,8 \\
\hline & - SLTA & 9 & 47,4 \\
\hline & $-\mathrm{PT}$ & 0 & 0 \\
\hline \multirow[t]{5}{*}{3} & Pekerjaan: & & \\
\hline & - IRT & 7 & 35 \\
\hline & - Petani & 3 & 15 \\
\hline & - Wiraswasta & 7 & 40 \\
\hline & - PNS & 2 & 10 \\
\hline \multirow[t]{3}{*}{4} & Informasi Imunisasi & & \\
\hline & - Pernah & 13 & 68,4 \\
\hline & - Tidak pernah & 6 & 31,6 \\
\hline \multirow[t]{3}{*}{5} & Sumber Informasi I & sasi & \\
\hline & - Petugas kesehatan & 13 & 68,4 \\
\hline & - Tidak pernah & 6 & 31,6 \\
\hline
\end{tabular}

Tabel 2. Distribusi frekuensi sikap sebelum penyuluhan dan sikap sesudah penyuluhan tentang penanganan febris pasca imunisasi DPT.

\begin{tabular}{lll}
\hline $\begin{array}{l}\text { Kategori } \\
\text { sikap }\end{array}$ & $\begin{array}{l}\text { \% sikap } \\
\text { pre test }\end{array}$ & $\begin{array}{l}\text { \% } \\
\text { post test }\end{array}$ \\
\hline Positif & 47,4 & 68,4 \\
\hline Negatif & 52,6 & 31,6 \\
\hline Wilcoxon sign rank test $\mathrm{p}=0,046$ \\
\hline
\end{tabular}

Kategori sikap positif pre test $47,4 \%$ post test $68,4 \%$ dan sikap negatif pre test $52,6 \%$ post test $31,6 \%$. Wilcoxon sign rank test: $\mathrm{p}=0,046$ dalam menghadapi febris pasca imunisasi DPT pada bayi usia 3-5 bulan.

Pegumpulan data penelitian dilakukan dengan kuesioner yang diberikan pada ibu yang memiliki bayi usia 3-5 bulan, diberikan dengan cara pre test dan post test kemudian dikumpulkan dan dianalisis dengan Wilcoxon Sign Rank Test.

Hal ini menunjukkan bahwa adanya pengaruh antara penyuluhan tentang penanganan febris pasca imunisasi DPT terhadap sikap responden.

\section{PEMBAHASAN}

Sikap ibu sebelum dilakukan penyuluhan

$\begin{array}{ccr}\text { Sikap } & \begin{array}{r}\text { responden } \\ \text { penyuluhan }\end{array} & \text { sebelum } \\ \text { tentang }\end{array}$ penanganan febris pasca imunisasi DPT menunjukkan bahwa $52,6 \%$ responden bersikap negatif. Sikap adalah sebagai keteraturan tertentu dalam hal perasaan (avektif), pemikiran (kognitif), dan predisposisi tindakan (konatif) seseorang terhadap suatu aspek dilingkungan sekitarnya. Sikap negatif disini berarti belum ada kemauan atau kemampuan responden dalam memberikan penanganan febris pasca imunisasi DPT. Faktor-faktor yang mempengaruhi sikap antara lain faktor intern yaitu faktor-faktor yang terdapat dalam diri orang yang bersangkutan seperti selektifitas dan pengalaman pribadi serta faktor ekstern yang merupakan faktor diluar manusia atau lingkungan (Azwar, 2011). Faktor-faktor yang mempengaruhi pembentukan sikap menurut Azwar (2011) adalah pengalaman pribadi, kebudayaan tempat tinggal, orang lain yang dianggap penting, media massa (informasi).

Sikap negatif reponden ini diduga dipengaruhi oleh informasi dan pengalaman pribadi responden. Berdasarkan hasil penelitian didapatkan bahwa sebagian besar dari responden $(68,4 \%)$ sudah pernah mendapatkan informasi tentang imunisasi. Selain itu semua informasi yang didapatkan berasal dari petugas kesehatan. Semakin 
bertambahnya informasi semakin bertambah pula pengetahuan yang didapat. Semakin banyak pengetahuan akan mempengaruhi responden dalam berfikir dan bersikap dalam hal imunisasi. Namun informasi yang diperoleh responden adalah informasi mengenai imunisasi secara umum saja seperti pengertian imunisasi serta tujuan atau manfaat imunisasi. Tetapi untuk pengetahuan mengenai imunisasi DPT secara rinci dan khusus belum didapatkan oleh responden. Hal ini berakibat pada masih adanya ibu yang bersikap negatif dalam penanganan febris pasca imunisasi DPT meskipun ibu tersebut sudah pernah mendapat informasi tentang imunisasi secara umum dari petugas kesehatan.

Sikap negatif responden juga dipengaruhi oleh beberapa factor diantaranya adalah pengalaman pribadi responden tentang penanganan febris pasca imunisasi DPT. Azwar (2011) mengatakan bahwa tidak adanya pengalaman sama sekali dengan suatu objek cenderung akan membentuk sikap yang negatif terhadap objek tersebut. Untuk dapat menjadi dasar pembentukan sikap, pengalaman pribadi haruslah meninggalkan kesan yang kuat. karena itu sikap akan mudah terbentuk. Pengalaman pribadi akan membentuk dan mempengaruhi penghayatan seseorang terhadap stimulus sosial. Dalam hal ini, responden belum pernah memberikan penanganan yang baik terhadap febris yang terjadi setelah imunisasi DPT.

Imunisasi DPT diberikan kepada bayi tidak hanya sekali saja, sehingga kejadian febris setelah imunisasi DPT sudah berulang terjadi namun mereka memberikan penanganan yang salah misalnya dengan memberikan kompres dingin. Hal ini disebabkan kurangnya informasi tentang imunisasi DPT secara khusus yang diperoleh ibu. Dari hasil penelitian didapatkan sikap responden sebelum dilakukan penyuluhan tentang penanganan febris pasca imunisasi DPT sebagian mempunyai sikap negatif yang lebih besar daripada sikap positif. Sikap responden yang negatif menunjukkan bahwa responden mendukung terhadap obyek sikap dengan indikator banyaknya jawaban setuju dan sangat setuju pada pernyataan-pernyataan negatif, sedangkan sedikit yang mempunyai sikap positif yang menunjukkan bahwa responden menolak terhadap obyek sikap, dimana ada yang setuju dan sangat setuju dengan pernyataan-pernyataan positif.

\section{Sikap ibu setelah dilakukan penyuluhan \\ $\begin{array}{llr}\text { Sikap } & \begin{array}{c}\text { responden } \\ \text { penyuluhan }\end{array} & \begin{array}{r}\text { sesudah } \\ \text { tentang }\end{array}\end{array}$} penanganan febris pasca imunisasi DPT menunjukkan bahwa $68,4 \%$ responden bersikap positif. Perubahan sikap dapat terjadi perlahan-lahan seiring dengan bertambahnya pengetahuan, informasi dan pengalaman yang didapatkan. Hal

ini sesuai dengan yang dikatakan oleh Azwar (2011) bahwa pembentukan sikap dapat dipengaruhi oleh beberapa faktor yaitu pendidikan, pengalaman, pengaruh orang lain yang dianggap penting, faktor emosi dan media massa. Selain itu, responden juga memiliki domain sikap, yaitu:

1) Menerima, yaitu bahwa responden mau memperhatikan stimulus yang diberikan tentang penanganan febris pasca imunisasi DPT 2) Merespon yaitu memberi jawaban dengan baik terhadap pertanyaanpertanyaan tentang penanganan febris pasca imunisasi DPT 3) Menghargai, yaitu memberikan arahan kepada sesama responden dalam hal berpartisipasi dalam penangan febris pasca imunisasi DPT Bertanggung jawab yaitu merasa bahwa responden perlu bertangggung

jawab terhadap penanganan febris pasca imunisasi DPT. Berdasarkan penelitian hampir setengah responden $(47,4 \%)$ berpendidikan SMA. Pendidikan yang cukup mempengaruhi pengetahuan seseorang untuk melakukan tindakan sesuai dengan kemampuan yang dimiliki dan sumber informasi yang diperoleh. Bila memiliki pemahaman yang baik membuat seseorang dapat berfikir kritis untuk melakukakan penanganan yang tepat saat anak mengalami febris. Ini sesuai dengan teori yang menyebutkan pendidikan adalah suatu kegiatan atau proses pembelajaran untuk mengembangkan atau meningkatkan kemampuan tertentu sehingga sasaran 
pendidikan itu dapat berdiri sendiri. Tingkat pendidikan turut pula menentukan mudah tidaknya seseorang menyerap dan memahami pengetahuan yang mereka peroleh, pada umumnya semakin tinggi pendidikan seseorang maka semakin baik pula pengetahuanya (Lukman 2008). Dalam hal ini, responden dapat dengan lebih mudah menyerap materi penyuluhan yang diberikan pada saat penelitian.

Hasil penelitian didapatkan sikap responden setelah dilakukan penyuluhan tentang penanganan febris pasca imunisasi DPT sebagian mempunyai sikap positif yang lebih besar daripada sikap negatif. Sikap responden yang positif menunjukkan bahwa responden mendukung terhadap obyek sikap dengan indikator banyaknya jawaban setuju dan sangat setuju pada pernyataan-pernyataan positif, sedangkan sedikit yang mempunyai sikap negatif yang menunjukkan bahwa responden mendukung terhadap obyek sikap, dimana ada yang setuju dan sangat setuju dengan pernyataan-pernyataan negatif. Pernyataan sikap berisi atau mengatakan hal-hal yang positif mengenai objek sikap, yaitu kalimatnya bersifat mendukung atau memihak pada objek sikap, pernyataan sikap juga berisi hal hal yang negative mengenai objek sikap, yaitu bersikap tidak mendukung ataupun kontra terhadap objek sikap yang hendak diungkap (Azwar, 2011). Keberhasilan suatu penyuluhan dapat dipengaruhi oleh factor penyuluhan, sasaran dan proses dalam penyuluhan (Effendi, 2003). Oleh karena itu digunakan metode ceramah yang efektif dalam penyampaian sehingga responden dapat mengerti dan memahami isi penyuluhan. Metode penyuluhan yang digunakan oleh peneliti adalah dengan memberikan materi penanganan febris setelah imunisasi DPT melalui presentasi yang menarik, pemberian leaflet dan juga memberikan souvenir kepada responden agar memiliki semangat dalam mengikuti penyuluhan. Oleh karena itu, dengan adanya penelitian ini diharapkan bidan sebagai ujung tombak pertama dapat memberikan informasi dan wawasan yang lebih, khususnya pada responden tentang penanganan febris pasca imunisasi DPT sehingga responden mampu bersikap berubah ke arah yang lebih positif dalam kehidupan sehari-hari. Sikap responden pada penelitian ini setelah diberikan penyuluhan masih ada yang negatif.

Untuk merubah sikap seseorang diperlukan waktu yang tidak singkat. Pemberian penyuluhan ini akan meningkatkan pemahaman seseorang terhadap penanganan febris pasca imunisasi DPT dengan tepat. Sikap yang negatif ini dimiliki oleh responden yang belum mengganggap febris adalah sesuatu yang perlu ditangani dengan tepat. Selain itu sikap responden setelah dilakukan penyuluhan masih ada yang negatif seperti pada responden nomor $8,11,14$, 16, 18, dan 19 bisa dikarenakan tingkat pendidikan yang berbeda sehingga tingkat pemahaman setiap orang juga berbeda. Bisa juga dikarenakan ketika diberikan penyuluhan ibu berada pada tempat paling belakang dan sibuk mengurus anaknya sehingga informasi yang disampaikan tidak dapat diterima dengan maksimal, ditambah dengan keadaan lingkungan yang ramai pada saat penyuluhan dilakukan. Sedangkan terjadi perubahan sikap dari negatif ke positif seperti pada responden nomor 10,12,13, dan 15 bisa dikarenakan responden benar-benar memahami apa yang disampaikan pada saat penyuluhan, dapat pula karena responden berada pada tempat duduk paling depan sehingga informasi yang disampaikan dapat diserap secara maksimal dan tidak terganggu oleh keramaian yang ada pada lingkungan saat penyuluhan dilakukan.

\section{Pengaruh penyuluhan terhadap sikap ibu menangani febris paska imunisasi DPT}

Berdasarkan hasil cross tabulasi menunjukkan bahwa $47,4 \%$ responden bersikap positif sebelum dilakukan penyuluhan dan $68,4 \%$ responden bersikap positif setelah dilakukan penyuluhan tentang penanganan febris pasca imunisasi DPT. Dari hasil analisa data dengan menggunakan uji statistik Wilcoxon, didapatkan nilai signifikansi dengan taraf 0,046. Dengan demikian antara penyuluhan dengan sikap responden mempunyai pengaruh yang 
signifikan. Namun terdapat 31,6\% responden yang masih mempunyai sikap negative setelah dilakukan penyuluhan, hal ini disebabkan oleh perbedaan umur, kecerdasan, dan penyuluhan yang dilakukan oleh peneliti yaitu mengenai bayi diberikan pakaian tipis tanpa selimut, pemberian obat penurun panas atau penghilang rasa nyeri, dan banyak minum ASI atau air buah yang belum dilakukan dengan baik. Hasil ini sesuai dangan pendapat Azwar (2011) bahwa struktur sikap terdiri dari 3 komponen yang saling menunjang yaitu komponen kognitif yang berisikan persepsi atau kepercayaan, komponen efektif yang berhubungan dengan masalah emosional subyektif seseorang terhadap suatu obyek sikap.

Komponen kognitif atau perilaku yang menunjukkan bagaimana perilaku atau kecenderungan berperilaku yang ada pada diri seseorang berkaitan dengan sikap yang dihadapinya. Penyuluhan merupakan suatu usaha atau kegiatan untuk membantu individu, kelompok atau masyarakat dalam meningkatkan kemampuan (perilaku) mereka dalam merubah sikap yang lebih baik (Notoatmodjo, 2003). Jadi dapat disimpulkan bahwa penyuluhan kesehatan dapat mempengaruhi pembentukan sikap seseorang dan sikap itu sendiri dipengaruhi oleh banyak faktor, meskipun berbagai informasi telah didapatkan belum tentu dia akan bersikap positif. Dengan didapatkannya pengaruh antara penyuluhan tentang penanganan febris pasca imunisasi DPT dengan sikap responden diharapkan adanya informasi yang telah diberikan melalui penyuluhan dapat meningkatkan sikap responden lebih positif dalam menghadapi masalah sebelum febris pasca imunisasi DPT. Responden harus mengetahui secara menyeluruh mengenai imunisasi DPT sehingga akan mampu mengerti dan memahami kemungkinan yang terjadi setelah dilakukan imunisasi DPT.

\section{SIMPULAN dan SARAN SIMPULAN}

Dari hasil penelitian dan analisa data yang telah dilakukan di dapatkan hasil sebagai berikut:
Sikap responden sebelum dilakukan penyuluhan tentang penanganan febris pasca imunisasi DPT adalah penilaian sikap negatif $47,4 \%$. Sikap responden setelah dilakukan penyuluhan tentang penanganan febris pasca imunisasi DPT adalah penilaian sikap positif $68,4 \%$. Ada pengaruh penyuluhan tentang penanganan febris pasca imunisasi DPT terhadap sikap responden dengan taraf signifikansi 0,046.

\section{SARAN}

Untuk tempat penelitian, diharapkan dapat menjalin kerja sama yang baik antara klien dan pelayanan kesehatan sehingga dapat meningkatkan kesehatan yang optimal kepada anak 3-5 tahun.

Untuk responden diharapkan pada responden lebih aktif lagi dalam meningkatkan pengetahuan dengan memperbanyak informasi tentang penanganan febris pasca imunisasi DPT.

Untuk institusi kesehatan bidan hendaknya lebih giat dan aktif dalam memberikan konseling, informasi, dan edukasi tentang imunisasi DPT khususnya penanganan febris pasca imunisasi DPT di lingkungan pendidikan secara berkala setiap bulan dan berkesinambungan.

Kepada peneliti selanjutnya, diharapkan penelitian ini dapat dimanfaatkan sebagai referensi penelitian selanjutnya.

\section{REFERENSI}

Azwar, S 2011, Sikap Manusia Teori dan Pengukursannya, Pustaka Pelajar Offset, Yogyakarta.

Fitriani, S 2011, Promosi Kesehatan, Graha Ilmu, Yogyakarta.

Hidayat, A A 2008, Ilmu Kesehatan Anak Untuk Pendidikan Kebidanan, Salemba Medika, Jakarta.

Hidayat, AA 2012, Metode Penelitian Kebidanan dan Teknik Analisis Data, Salemba Medika, Jakarta.

Notoatmodjo, S 2010, Promosi Kesehatan Teori dan aplikasi, Rineka Cipta, Jakarta.

Nursalam 2011, Konsep dan Penerapan Metodologi Penelitian Ilmu Keperawatan, Salemba Medika, Jakarta.

Muslihatun, WN 2010, Asuhan Neonatus Bayi dan Balita, diakses tanggal 
Jurnal Ners dan Kebidanan, Volume 1, No. 1, Maret 2014

15

April

2013,

Markum 2005, Imunisasi DPT, diakses 15

<http://coretansidjeck.blogspot. com/2012/09/perubahan-suhuApril 2013, tubuh-bayi-setelah.html>. <http://www.blogger.com>.

Depkes RI 2005, Jadwal Pemberian Imunisasi, diakses 15April 2013, <http://www.depkes.com>. 